\title{
ADMINISTRATIVE LAW: POWER OF SECRETARY OF LABOR TO SUBPOENA DOCUMENTS UNDER LANDRUM-GRIFFIN ACT
}

$T_{\text {HE power of the Secretary of Labor to investigate for past or pros- }}$ pective violations of the Labor Management Reporting and Disclosure Act $^{1}$ was recently dealt a harsh blow by a federal district court. In Mitchell v. Teamsters, Local Union $299,{ }^{2}$ the District Court for the Eastern District of Michigan held that Section 6or of the act did not require the Union to comply with certain subpoenas duces tecum issued at the request of the Secretary of Labor. The court also indicated that if the statute did require compliance with the subpoenas it would be violative of the fourth amendment to the United States Constitution.

The controversy arose when two locals of the Teamsters Union sought temporary restraining orders to prevent the enforcement of the subpoenas. ${ }^{3}$ All parties agreed that the Secretary had no probable cause on which to base his request for the documents in question. The Secretary, however, contended that the statute authorized such a request and that the statute was constitutional. The Union argued that the Congressional power to regulate union affairs under the commerce clause extended only to activities substantially related to the collective bargaining function and also that the subpoenas were improper because the requested information concerned records kept prior to the passage of the act. ${ }^{4}$ The court's conclusion that the subpoenas were unauthorized by statute or that the statute was unconstitutional, however, seems to be based on arguments the parties felt were relatively unimportant. Regardless of the reasons presented by the court, its holding appears erroneous.

The court's holding that the subpoenas were unenforceable was

\footnotetext{
${ }_{29}$ U.S.C.A. \$ $40 x$ (Supp. 1960).

2 19x F. Supp. 229 (E.D. Mich. 196x).

'The suit for a restraining order was dismissed by stipulation because service could not be had on the Secretary of Labor. The Secretary then petitioned the court for an order directing the unions to show cause why the subpoenas should not be enforced. This proceeding resulted in the decision in the instant case.

"Brief for Respondent, p.5, Mitchell v. Teamsters, Local Union 299, 191 F. Supp. 229 (E. D. Mich. 1961).

${ }^{5}$ Out of a total of 38 pages of brief the unions devoted 7 pages to those points the court apparently felt were decisive. The government addressed Io of its 26 pages to these points.
} 
based on a construction of Section 6oI of the act which, in effect, requires that the Secretary have probable cause for an investigation of union records. The legislative history of the Act does not support such a construction: ${ }^{8}$

As originally worded, this section would have given the Secretary the authority to investigate the books and records of persons reporting under the act only when he had probable cause to believe that a person had violated the provisions of the act. ... But the words "probable cause" would throw a monkey wrench into the Secretary's investigative machinery. ... the Secretary could be dragged into court until the question of probable cause had been decided. Under nearly every statute requiring the filing of reports, the Administrator can conduct "spot check" investigations unhampered by the "probable cause" requirement. Our amendment rewrites this section to give the Secretary investigatory power when he beheves it necessary in order to determine whether a violation has occurred or is about to occur.

Clearly the act was designed to prevent the very requirement that was imposed in the instant case.

The judicial construction given to similar provisions of other acts is also opposed to this decision. Speaking of subpoenas under the Fair Labor Standards Act, the Supreme Court in Oklahoma Press Publishing Co. v. Walling stated that "the very purpose of the subpoenas and of the order, as of the authorized investigation, is to discover and procure evidence, not to prove a pending charge or complaint." ${ }^{\prime \prime}$ The Court likened the investigatory function of the Administrator under this statute to that of a grand jury, noting that the inquiry should not be "limited ... by ... forecasts of the probable result of the investigation." Similar determinations have also been reached under the National Labor Relations Act. ${ }^{\circ}$

In its search for the constitutional limits imposed by the search and seizure provisions of the fourth amendment the court looked to two famous cases, FTC v. American Tobacco Co., ${ }^{10}$ and Oklahoma Press

'S. REP. No. 187, 86th Cong. Ist Sess. 91 (1959).

7327 U.S. I86, 201 (1945).

${ }^{8} I d$. at 216 .

- NLRB v. Northern Trust Co., $x_{4} 8$ F.2d 24, cert. denied, 326 U.S. 73I (1945); Cudahy Packing Co. v. NLRB, II 7 F.2d 692 (1941).

${ }^{10}{ }_{264}$ U.S. $298(1924)$. In this case complaints had been filed with the Federal Trade Commission charging respondents with regulating the resale prices of their commodities and the Commission, pursuant to a Senate resolution, was engaged in an investigation of these complaints. The FTC ordered the American Tobacco Co. and P. Lorrillard \& Co. to produce a variety of letters, telegrams and reports to salesmen and certain named corporations. The court denied enforcement of the subpoenas. Despite 
Publishing Co. v. Walling. ${ }^{11}$ In the American Tobacco Co. decision Mr. Justice Holmes had strongly admonished courts against permitting fishing expeditions into private papers on the chance that some evidence of crime might be disclosed. The court in the instant case categorized its problem as one of determining whether the American Tobacco Co. case had been delimited by the more recent Oklahoma Press Publishing Co. decision. Indicating that any relaxation of the American Tobacco doctrine applied only to corporations, ${ }^{12}$ the court concluded that even if some relaxation applicable to unions had occurred the subpoenas in the instant case failed to meet this test. Upon closer analysis, however, this conclusion appears to be in error.

In support of its position, the court looked to that part of the Okla-

Mr. Justice Holmes admonition against fishing expeditions, however, the narrow holding was that the Commission had failed to show that all documents requested were relevant to the inquiry.

${ }^{11} 327$ U.S. 186 (1945). This opinion consolidated the questions presented by two Courts of Appeals cases. The first was Oklahoma Press Publishing Co. v. Walling, 147 F.2d $65^{8}$ (roth Cir. 1945), the second, Walling v. News Printing Co., Inc., I48 F.2d 57 (3d Cir. 1945). In both instances the administrator had requested certain documents by subpoenas duces tecum, pursuant to sections 9 and II (a) of the Fair Labor Standards Act. After hearings under show cause orders, the district court allowed enforcement of the subpoenas. Enforcement was denied in the second case. The Oklahoma Press decision was affirmed by the Circuit Court while the News Printing Co. decision was reversed. The reasoning of the Circuit Courts differed, however, and certiorari was granted by the Supreme Court. The decisions in both cases were affirmed.

${ }^{12}$ In reaching this conclusion the court reasoned that Oklahoma Press had concerned only corporations and consequently that any relaxation of the fourth amendment as applied to unions was inadvisable. In support of this proposition the court cited N.A.A.C.P. v. Alabama, 357 U.S. 449 (1958), holding the N.A.A.C.P. a proper party to assert the rights of individual members to refuse to disclose membership in the organization. After determining that the subponeas requested in the instant case were sufficiently broad to require disclosure of union membership lists, the court concluded it would "not by judicial legislation encourage the extension of the 'fishing expedition' into the field of personal rights." Mitchell v. Teamsters, Local Union 299, I9I F. Supp. 229, 233 (E.D. Mich. 1961).

The conclusion that Oklahoma Press is inapplicable to unincorporated associations is highly questionable in light of United States v. White, 322 U.S. 694 (1944), which held that for fifth amendment purposes a union may be treated as a corporate entity. In making this determination the Supreme Court stated: "[The] . . . test is whether one can fairly say under all the circumstances that a particular type of organization has a character so impersonal in the scope of its membership and activities that it cannot be said to embody or represent the purely private or personal interests of its constituents, but rather to embody their common group interests only. . . . labor unions-national or local, incorporated or unincorporated-clearly meet this test." United States v. White, supra at 7or. It would seem that this reasoning deserves more consideration than is apparent in its summary dismissal by the court because "Fifth Amendment problems are not present here." Mitchell v. Teamsters, Local Union 299, supra at 232. 
homa Press opinion which states that the "relevancy and adequacy or excess in breadth of the subpoena are matters variable in relation to the nature, purposes and scope of the inquiry," concluding: ${ }^{13}$

Therefore, if the judiciary is to play any role ... it must make an independent determination of the basis or impelling motive of the investigation. The query then presents itself: how can it be determined whether or not the subpoena can be tested for relevancy, adequacy or excess in breadth?

The Secretary, by admission, had no substantial reason for requesting the documents covered by the subpoenas. ${ }^{14}$ Accordingly, the court reasoned that if the statute permitted such a request, it had eliminated the means to test the subpoenas and was, for this reason, unconstitutional.

The two cases relied on by the court do not, however, adequately indicate the present state of the law. To be sure, the American Tobacco decision did refuse to allow liberal use of the administrative subpoena. However, Brown v. United States ${ }^{15}$ decided four years later, relaxed many of these restrictions. This case distinguished Hale v. Henkel, ${ }^{16}$ the early case that had been the basis for Holmes' admonition in American Tobacco, and held that a subpoena directed against an unincorporated association of manufacturers was not too broad even though it requested all letters and telegrams passing between the association and its predecessor in interest. Oklahoma Press is usually cited as reflecting the weakening trend against fishing expeditions. ${ }^{17}$ This case does suggest that the role of the judiciary is to prevent abuse of the investigative process. However, it also indicates that this process does not offend the fourth amendment if the disclosure sought is reasonable: ${ }^{18}$

The requirement of "probable cause supported by an oath of affirmation" literally applicable in the case of a warrant, is satisfied in that of an order for production by the court's determination that the investigation is authorized by Congress, is for a purpose Congress can order, and the documents sought are relevant to the inquiry.

Since the court seems to concede that the investigation is for a pur= pose which Congress may authorize, ${ }^{10}$ the remaining problem is to

\footnotetext{
${ }^{13}$ Mitchell v. Teamsters, Local Union 299, 191 F. Snpp. 229, 232 (E.D. Mich. I96I).

${ }^{16} I \dot{d}$, at $229-230$.

15276 U.S. 134 (1928).

${ }^{16} 201$ U.S. 43 (Ig06).

${ }^{17}$ Davis, The Administrative Power of Inovestigation, 56 YALE L.J. IIII, II3 I (1947).

${ }_{18}$ Oklahoma Press Publishing Co. v. Walling, 327 U.S. I86, 209 ( I945).

${ }^{10}$ The court passed over the argument of the unions that Congress has power to
} 
determine which documents are relevant to the inquiry. The test of relevancy today seems to be based on a determination of whether the documents requested may disclose a violation of the act, not whether they are relevant to the stated purpose of the inquiry. Indeed, one presently applied test seems to be "is it impossible that the records requested will show a violation?"20

The Supreme Court in United States v. Morton Salt Co. ${ }^{21}$ passed on the question of relevancy as required by the fourth amendment, noting that the requirement can be met "even if one were to regard the request for information . . . as caused by nothing more than official curiosity . . ."22 Thus it appears that the Constitution does not, as supposed by the court in the instant case, require that the administrator have some element of probable cause before subpoenas duces tecum may be issued. Further, since the Secretary requested only records required to be kept by law, it is quite possible that these documents would disclose a violation.

Because neither the language of the statute nor the requirement of the fourth amendment supports the conclusion of the district court in the instant case, it is probable that this decision will be reversed by an appellate court. If such a reversal is not forthcoming, the decision will greatly hamper investigations under the Landrum-Griffin Act.

regulate only those union activities substantially related to collective bargaining, apparently assuming that such power exists. See Johnson v. Local Union No. 58, International Brotherhood of Electrical Workers, i 8 I F. Supp. 734 (E.D. Mich. 1960), upholding the constitutionality of this statute.

${ }^{20}$ Whiteside Ford, Inc. v. United States, 206 F.2d 627, 634 (9th Cir. 1953).

${ }_{21} 338$ U.S. 632 (1950).

22 Id. at 652 . 